\title{
Use of Strategic Management Accounting in the determination of costs in SMEs in the furniture sector
}

\section{Uso de la Contabilidad de Gestión Estratégica en la determinación de costos en PYMES del sector mueblero}

LOMELI-RODRÍGUEZ, Sandra Eva†*, PELEGRIN-MESA, Arístides, SÁNCHEZ-BATISTA, Antonio and TORRES-MORA, Inés Josefina

Universidad de Guadalajara, Centro Universitario de la Ciénega. Departamento de Contaduría y Finanzas.

ID $1^{\text {st }}$ Author: Sandra Eva, Lomeli-Rodríguez / ORC ID: 0000-0003-1161-6989

ID $1^{\text {st }}$ Co-author: Arístides, Pelegrin-Mesa / ORC ID: 0000-0001-8723-9046

ID $2^{\text {nd }}$ Co-author: Antonio, Sánchez-Batista / ORC ID: 0000-0003-3352-9368

ID $3^{\text {rd }}$ Co-author: Inés Josefina, Torres-Mora / ORC ID: 0000-0002-3060-4900

DOI: $10.35429 / J B D S .2021 .20 .7 .10 .14$

Received September 11, 2021; Accepted December 15, 2021

\begin{abstract}
Determining cost in industry of all sizes represents a starting point for determining your desired returns. For this reason, the precise calculation matters greatly to the administration of any economic entity. We are currently facing the so-called knowledge era and where changes are looming permanent, so the colloquially called traditional accounting systems must be reinforced with innovative techniques. The objective of this research work is to propose to Small and Medium-sized companies (PYMES) dedicated to the manufacture of furniture an innovative tool with which the cost is determined starting from a hybrid counting system, a traditional system strengthened with a technique of Strategic management. The Cost Management System proposed by this research is based on the conclusion found in the theoretical framework that a system is not something isolated, but is formed as a gear of techniques, procedures and techniques; according to the needs of the companies under study. To carry out the present research work, a diagnostic analysis of the furniture SMEs was carried out, where information was obtained regarding the characteristics for the determination, measurement, analysis and cost management of these companies. According to the result of said analysis, the system proposal is presented, which is in the validation process for its dissemination and, where appropriate commercialization, prior to its registration. If the SMEs dedicated to the manufacture of furniture have a system according to their characteristics, it will be possible to determine with certainty indicators that are essential for making strategic decisions that infer in the improvement of the administration of the SMEs under study.
\end{abstract}

Cost in SMEs, furniture SMEs, Strategic management

\section{Resumen}

La determinación del costo en la industria de todos los tamaños representa un punto de partida para la determinación de sus rendimientos deseados. Por tal razón el cálculo preciso importa en gran manera a la administración de todo ente económico. Actualmente nos estamos enfrentando a la denominada era del conocimiento y donde los cambios se vislumbran permanentes por lo que los sistemas contables llamados coloquialmente tradicionales deben ser reforzados con técnicas innovadoras. El objetivo del presente trabajo de investigación es proponer a las empresas Pequeñas y Medianas (PYMES) dedicadas a la fabricación del mueble una herramienta innovadora con la que se determine el costo partiendo de un sistema de contos hibrido, un sistema tradicional fortalecido con un técnica de Gestión estratégica. El Sistema de Gestión de Costos que propone la presente investigación se funda en la conclusión encontrada en el marco teórico respecto a que un sistema no es algo aislado, sino que se conforma como un engranaje de técnicas, procedimientos y técnicas; de acuerdo con las necesidades de las empresas objeto de estudio. Para llevar a cabo el presente trabajo de investigación se realizó un análisis diagnostico de las PYMES muebleras donde se obtuvo información respecto a las características para la determinación medición, análisis y gestión de costos de estas empresas. De acuerdo con el resultado de dicho análisis se presenta la propuesta del sistema, misma que se encuentra en proceso de validación para su difusión y en su caso comercialización, previo a su registro. Si las PYMES dedicadas a la fabricación de muebles cuentan con un sistema acorde a sus características será posible determinar con certeza indicadores que le son indispensables para la toma de decisiones estratégicas que infieran en la mejora de la administración de las PYMES objeto de estudio.

Costos en PYMES, PYMES muebleras, Gestión Estratégica

Citation: LOMELI-RODRÍGUEZ, Sandra Eva, PELEGRIN-MESA, Arístides, SÁNCHEZ-BATISTA, Antonio and TORRES-MORA, Inés Josefina. Use of Strategic Management Accounting in the determination of costs in SMEs in the furniture sector. Journal of Business Development Strategies. 2021, 7-20: 10-14

\footnotetext{
* Correspondence to Author (email: sandylome @ hotmail.com)

$\dagger$ Researcher contributing first author
} 


\section{Introducción}

In Mexico, $98 \%$ of the manufacturing industries dedicated to the manufacture of furniture are SMEs (Small and Medium Enterprises) according to the National Statistical Directory of Economic Units (DENUE) of the National Institute of Statistics and Geography (INEGI), of these, $95.48 \%$ are micro, $3.87 \%$ small and only $0.65 \%$ medium based on the number of workers they employ.

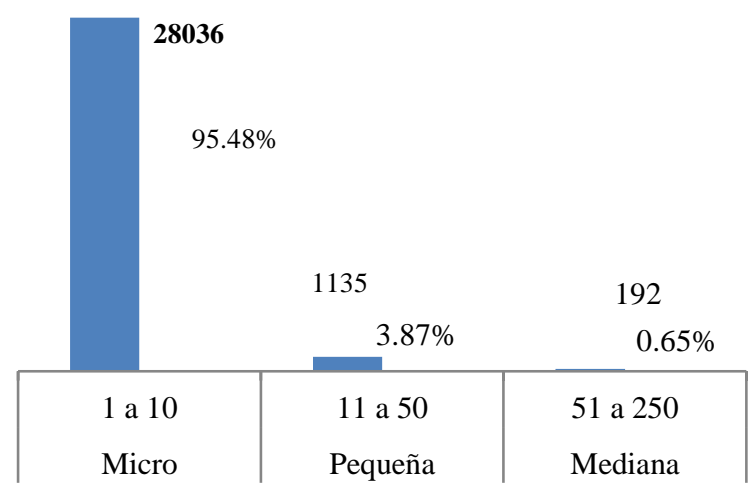

Graphic 1 Furniture SMEs in Mexico Fountain: DENUE (2021)

In Mexico, Strategic Management Accounting acquires greater relevance due to the changes that affect Accounting in all its forms; fiscal, financial and management. Facts generated by tax reforms that have an impact on the financial and administrative or management situation of any organization. Regarding strategic management accounting fully related to the internal control of organizations in which it is included Cost accounting primary base for decision making, as indicated (Arredondo, 2015) "Cost Accounting supports Accounting Financial and Administrative Accounting to give you information on costs and expenses for decision making".

In the same way (Valeria \& Soto, 2017) points out that cost indicators are used for the control, evaluation, planning and development of information systems for organizations. Interesting work has been done on management accounting in SMEs, such as the article Mite Albán, (2018), which points out: the adoption of management accounting strategies according to the literature review decreases in a business segment known as SMEs, in a lapse of almost fifty years, of analysis of articles related to the social sciences in Scopus and the Web of Science, 4827.
Only 13 concerned accounting, costs, and management in small businesses. Another publication, (Baigorria, 2018) states: despite the benefits of Accounting, SMEs use it only in order to comply legal and tax requirements, becoming an expense without benefits. SMEs are family businesses, with little professional development, with administrations little interested in giving an adequate use to this set of tools. This lack of interest has meant an obstacle in the speed and precision of transcendental decisions, that undoubtedly, can contribute to improving managerial performance. (Peña, 2005).

We find ourselves with two major challenges, on the one hand, despite the need for accurate information to decide, ignorance and in other cases, the costs that can generate tools designed for large companies, have limited the development of strategic management accounting in SMEs. In another order, scientists have focused their efforts on control and decision-making of large companies, and the SME segment, cannot afford that result. That is why this scientific work seeks focus on the use of a strategic management technique according to SMEs dedicated to the manufacture of wooden furniture.

\section{Background}

In the current era we are living, the use of technology, the internet and the maturation of globalization to which many have intensified authors have called generation 3.0, we can observe relevant changes in this regard in all areas and do not say in the prosecutor, economic and financial companies worldwide. In addition to this, the competition between global peers, the management of information current electronics and new forms of marketing. Aspects that Management Accounting can not remain alien.

With this, Accounting can be considered as a Techno-science, defined by Echeverria (2005) as a way of practicing the science and technology that emerged in the 80s in the US (United States of America) and that extends to other countries. Techno-science coexists with conventional science and technology since each scientific discovery has a conditioned state for the need for social development and at the same time its impact on Society. 
Reviewing the theoretical framework in this regard we can divide the development of accounting into stages or periods for a better analysis, the empirical period, the classical or methodical and the scientific. In the empirical beginning with the emergence of sedentary peoples who had the need to account for family assets, then followed by the Babylonian and Egyptian empires (ancient) in which there was already to be control of taxes of oppressed people and other resources, then come the Greeks and the Roman Empire where it already began with the control of money and capital accounts. In the empirical period it could be said that it was by the Middle Ages then, there were isolated procedures.

Already in the classical period it begins with the systematized use of the double game and begins the great development of science between the sixteenth and seventeenth century with the theorists Colon, Copernicus, Galileo, Newton and Pacciolo. French, Lonbarda, Tuscany, personalist and Bosta schools emerge. It is followed by the scientific period in which the development of capitalism in its upper phase, manifested in the concentration of capital and the development of large industry elevated the role of accounting to management science and to some dispute with other economic sciences over the object of research.

\section{Costs and Accounting of Strategic Management}

The main objective of financial accounting is to be oriented to the third user of accounting information, call it the treasury, banks, investors, etc. which can be nourished, from the accounting information that arises from a balance sheet, of a series of data for decision making. But this information suffers from a great drawback, it is relative to the past, which in a sense disqualifies it from making decisions regarding the future.

What every entity seeks with the use of accounting is to provide timely, truthful and reliable information oriented to decision making. For this reason, the use of Strategic Management Accounting is essential. Cost accounting is an essential tool for the decision-making of economic entities of all sizes, not undermining the SMEs.
For this work we will refer to Strategic Cost Management (CGE). In traditional cost accounting simply the cost is determined with the use of a system, either by processes or by orders, depending on the characteristics of the economic entity in question. By making use of strategic tools we would find strategic cost management which will focus on the use of traditional accounting incorporating the strategic issue within the scope of costs, which is already novel.

Management accounting has distinguished itself by adopting a strategic character that has been reflected in the current systems, instruments and models it encompasses. Such are the cases of activity based costing (ABC); local information systems (LS); the balanced scorecard (BSC); activity management (AM); activity-based management (ABM); life cycle costing (LCC); and target costing (TC), among others. (Martinez y Blanco, 2017)

The great strength of SCM is that it addresses each link in the value chain, strategic positioning and cost drivers, taking into account external cost-incurring events such as environmental costs, logistics costs, balanced scorecard (BSC) and quality costs.

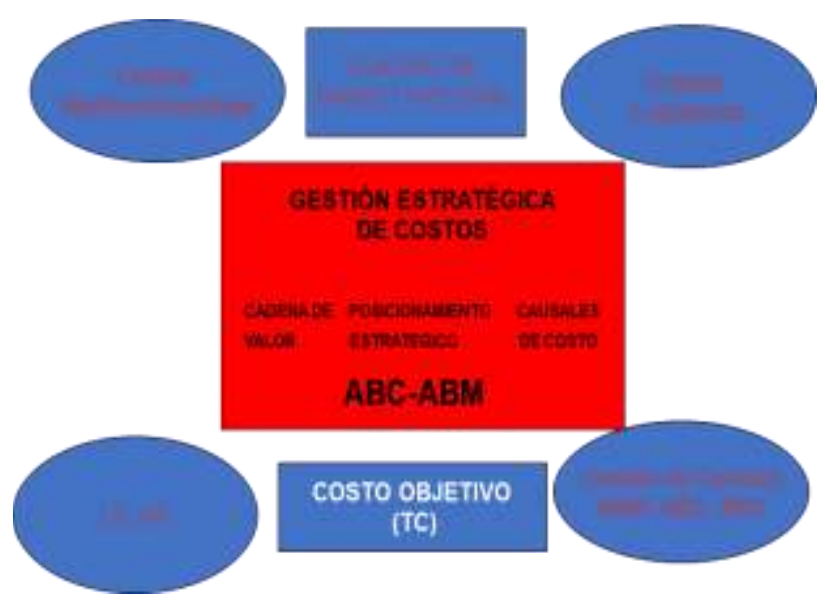

Figure 1 Strategic Cost Management (SCM) Source: Own elaboration

As can be seen in Illustration 1 to locate the techniques that strengthen traditional accounting with novel and useful strategies for cost calculation and management, we can call them guidelines for managing cost strategically. 


\section{Costs for SMEs}

A diagnostic study was applied to $100 \%$ of the companies dedicated to the manufacture of wood furniture in Ocotlán Jalisco, Mexico; registered as members of AFAMO (Asociación de Fabricantes de Muebles de Ocotlán A.C.) as of the date of the research. Of the 262 furniture industries that INEGI claims exist in Ocotlán only seventy are members of AFAMO. This industrial zone was determined as the universe of study because it is considered the capital of furniture, one of the most influential nationally in this branch. (Lomelí, 2018). Most SMEs have deficiencies in their cost information systems. As a result, the information used for decisionmaking lacks the required relevance, reliability and timeliness. Hence the importance of proposing an integral methodology that modifies this process and makes it possible to determine product costs, providing greater competitive advantages at a global level.

Most SME entrepreneurs determine the cost of their product in order to have a basis for setting (or negotiating) the selling price and, in addition, they calculate their business results as the difference between their revenues and total costs. Unfortunately, today these entrepreneurs spend more time increasing their production than analyzing costs, when an improvement in productivity would allow them to simultaneously manufacture more and reduce costs. It is common to find technical or conceptual errors in cost reports: misclassifications, duplicated information, simplistic or unrealistic projections, among others. Based on the results found, a traditional costing system is proposed with the use of a strategic management technique to facilitate costing for SMEs engaged in furniture manufacturing.

\section{Costing System using CEMs}

The Cost Management System proposed in this research is based on the conclusion found in the framework according to the needs of the companies under study. The characteristics of the furniture SMEs are very clear, they determine their costs empirically, so by proposing this system they will have a basis for the determination of the cost starting with the determination of the sales price, as the basis of the cost.
First of all, it is extremely important to know the business (characteristics of the product and/or service, production and/or provision processes, to know the market where it operates, including sales and distribution channels).

To know the existing information circuits: what information is currently available, who produces it, who its recipients are, the information gaps for new purposes, in other words, the flow of costs. A survey of the different operational circuits and, depending on the particular case, it could be divided into different objectives. Once the objective has been defined, for example production: a map should be drawn up with the different production activities (they could be cost centers) that consume resources and where the linkage of the activities can be observed.

The aforementioned mapping of activities is a very important tool to be able to follow up, measure efficiency, set standards to be met and consequently make improvements in the different processes.

Due to their nature and mode of operation, small and medium-sized companies have very peculiar characteristics that are a function of their size, operations and the accumulation of costs, making the use of an Order-Based Costing System interesting and pertinent. The author assumes the criterion that for the Mexican context, the use of this type of system in SMEs is inserted within the current purposes for these companies to achieve the goals and strategies foreseen.

In these entities, prices are calculated based on cost recovery and a certain profit margin; however, why not use market-based pricing systems, also known as Genka Kikaku, Target Cost or Objective Cost? In these systems, starting from a price accepted by the market, the company subtracts the desired profit margin, obtaining the cost by difference. This thinking is the one that adapts to the small and mediumsized companies that are the basis of this research. In view of this scenario, the proposal of the "Complete Cost System by Production Orders or Orders using the Objective Costing Management Technique" (SCPO) arises, which is proposed according to the characteristics of the case study companies, an innovative idea that breaks with previous paradigms. 
The system runs in nine stages, the proposed procedure is similar to the classic systems and therefore it is not complex but it does require to be detailed. And by including the target cost in the model, the traditional perspective is changed by the Japanese philosophy of customer orientation, to consider that the selling price is determined by the market and in this way it is the customer who conditions the maximum cost to be incurred, which will be achieved with teamwork by joining all efforts to achieve planning and cost reduction. For this, it is considered that there must be a change of mentality in the whole organization, forming a proactive group that allows them to be oriented towards their permanence in the market and consequently their growth and development in all the senses in which the company operates. The system is in the process of validation, which has shown its efficiency by running correctly and the pertinent adjustments are being made according to the results.

The product of this research will be a very useful tool for the companies under study, and it will be possible to extend it to other types of companies with similar characteristics.

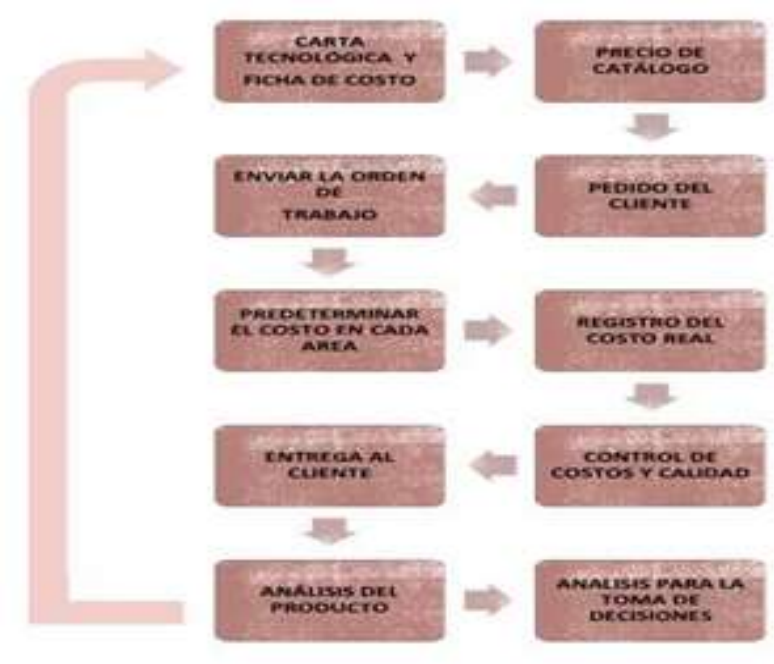

Figure 2 Logical-Methodological Schema Source: Own Elaboration

\section{Conclusions}

The diagnostic study provided the basis for the problem and affirmed that the furniture SMEs did not have a strategic cost management model. The integration of a CEM tool helps to determine the necessary production volumes and to determine the most suitable mix of items to be produced.
The implementation of an Order-Based Costing System with a CEM approach in small and medium-sized enterprises (SMEs) in Mexico is a disruptive technology that will enable these entities to perform analysis, make decisions and propose increasingly competitive prices.

\section{Referencias}

Arredondo, G. M. (2015 ). Contabilidad y análisis de costos. México: Grupo Editorial Patria.

DENUE. (7 de noviembre de 2021). Directorio Estadísticio Nacional de Unidades Económicas. Obtenido de Instituto Nacional de Estadística y Geografía:

https://www.inegi.org.mx/app/mapa/denue/

Echeverria, J. (2005). La Revolución Tecnocientífica. México: Itesm. Recuperado el 21 de noviembre del 2021 de: https://confines.mty.itesm.mx/articulos2/Echev erriaJ.pdf

LOMELÍ RODRÍGUEZ, S. E. Sistema de costos tradicional aplicable a Pymes. Un estudio para empresas de la industria del mueble en México. Revista Cubana de Finanzas y Precios, [S.l.], v. 2, n. 4, p. 13-23, dec. 2018. ISSN 2523-2967. Disponible en: <https://www.mfp.gob.cu/revista_mfp/index.ph p/RCFP/article/view/03_V2N42018_SLR>.

Fecha de acceso: 09 nov. 2021

Martínez H. R. \& Blanco D.M., Aproximación a la contabilidad de gestión estratégica: una mirada a su evolución y vigencia. DOI: https://doi.org/10.11144/Javeriana.cc18-46.acge

Valeria, G. S., \& Soto, C. (2017). Contabilidad de Costos. México: ECOE. 